One project which was commenced in the year under review was the automatic process plant control. This is concerned with the development of electronic automatic control equipment suitable for plant and process control automation and, for example, for the control of power stations and chemical plants. It contemplates the development of a range of standard equipment which will permit electronic analogue and mixed analogue/digital computing techniques to be used for this purpose, the individual elements being capable of assembly in a variety of ways to enable control systems to be designed as required for any particular plant.

The work is being undertaken by an established firm in the electronic computing and control engineering fields, which is sharing the cost with the Corporation. The project is still in its early stages, but work has started on the design of circuit elements and components, and on the study of potential plant applications.

\title{
FGTTAL AND NEONATAL PHYSIOLOGY
}

A

LTHOUGH there have been great reductions in infantile mortality within the present century, it is only now being realized how much can be done to reduce mortality before birth and in the first days after it. The application of fundamental physiological principles to the management of premature infants has become a study in its own right. These principles were recently examined in the British Medical Bulletin*, the contributions varying from investigations of blood pressures in new-born babies, the e.cquirement of immunity and immunological tolerance, protein and amino-acid movements in the fotus and new-born animal, transport mechanisms in the placenta and red cells, enzyme development, the newer aspects of placental histology, fœetal endocrinology, and the chemoreceptors and their function in the aortic-pulmonary body.

Among the more outstanding experimental work is a review by Dr. $R$. Deanesley of the present position in foetal endocrinology. Experimental operations by Jost, Wells and their collaborators, on pregnant rabbits and rats, and on fœetuses in utero, have shown that in these animals the pituitary and testes become active before birth and play a decisive part in differentiation. Thyroid and adrenal development is controlled by the fœtal pituitary. The developing fœtus at certain stages can react to exogenous hormones which reach it directly or through the placenta. The fact that the endocrine glands are active in the foetus carries no implication that their secretions can affect the maternal physiology.

In their review of the foetal kidney, Miss Pauline Alexander and Dr. D. A. Nixon show that development of function in the metanephros is spread over a period of time-some activities appearing earlier than others.

The onset of glomerular filtration precedes tubular activity so that large volumes of urine may be passed into the amniotic or allantoic sacs from an early age. Subsequent appearance of tubular activities results first in the production of a hypotonic and, later, a hypertonic urine. The maximal osmolarity of the urine is low by adult standards because of the low excretion of solute. The renal capacity to acidify the urine is limited in the early stages, in part by the very low excretion of phosphate. The glomerular filtration-rate appears to be somewhat labile at first, and the factors leading to its stability in later life are not known. Ratios for the clearance of $p$-aminohippurate: inulin suggest that the supply of blood to

* British Medical Bulletin, 17, No. 2 (May 1961): Fotal and Neonatal Physiology. Pp. 79-176+8 plates. (London: British Council, 1961.) 208 . the kidney is low in foetal life in comparison with that in the adult, and this may limit its functional capacity considerably.

The stage of metanephric develop.nent at which a foetus of any particular species attains an independent existence will determine its initial renal problems.

Dr. Heather J. Shelley has investigated reserves of glycogen and their changes at birth and in anoxia. However, there is no reliable information on the glycogen reserves of the new-boin human infants, but, by analogy with other species, they probably have a high concentration of liver glycogen and a fair amount of muscle glycogen. New-born babies have been known to withstand anoxia for up to $30 \mathrm{~min}$. (Bullough, 1958), so it is likely that their cardiac glycogen concentration is also high. Since lactation is not established in man until $24-48 \mathrm{hr}$. after parturition, the new-born baby must be particularly dependent on its reserves; if its liver glycogen falls as rapidly as in other species it will be in a precarious metabolic state for several days. If kept warm, the new-born baby can survive for several days without food, but if exposed to cold it later dies of hypoglycæmia (Mann and Elliot, 1957), probably the result of an attempt to maintain its body temperature (Bruck, 1959). It is therefore possible that factors which reduce the glycogen content of the fœtus in utero or at birth may jeopardize the infant's ehances of survival after birth, and future work must determine to what extent the deleterious effects of maternal nutrition, placental insufficiency and birth asphyxia may be the consequence of inadequate glycogen reserves.

The ability of young mammals to withstand a total lack of oxygen was considered by Dr. Joan Mott. She believes that the practical conclusion to be drawn from the present state of knowledge of the conditions under which anoxie survival is possible is that the carbohydrate stores, particularly of the heart, should be protected from dissipation. Resynthesis of carbohydrate does occur, but may bo limited by the rate of entry of glucose into the cell. Thus the factor of vital importance is the store of carbohydrate already available within the cardiac cells. Repeated episodes of anoxia or hypoxia are cumulatively as well as individually dangerous, and it is probable that, if the $p H$ is not restored to normal level, a stage is reached at which glycolysis may be completely inhibited. Repeated anoxic episodes may also exhaust the liver glycogen and lead to hypoglycæmia, so that maintenance of the circulation might be insufficient to protect the brain from injury. 
From the available evidence showing the reaction of the new-born animal to environmental temperatures, Dr. June Hill suggests that the metabolism of the new-born of a warm-blooded species often differs from that of the adult animal in two important respects: first, the new-born animal has a lower basic metabolic rate than is appropriate for its surface area; and secondly, per unit surface area, the new-born animal has a smaller maximal metabolic response to cold. Thus the heat production of the new-born animal, both minimal and maximal, is lower per unit surface area than that of the adult. The degree of immaturity at birth probably determines to what extent the metabolism of the new-born deviates from the adult pattern.

In addition, the new-born animal often has a coat of lower effective insulating power than that of its parent; this is partly because the new-born is smaller than the adult, and is partly a specific attribute of immaturity. This means that, per unit surface area at a given environmental temperature, the new-born animal loses heat much more readily than the adult.

These facts underlie, and go far to account for, the difficulties which many new-born animals experience in maintaining a stable internal bodytemperature.

\section{LIFE AND SCIENTIFIC WORK OF SIR JAMES HALL}

T HE Bruce-Preller Lecture of the Royal Society of Edinburgh was delivered on June 5 by Dr. V. A. Eyles, formerly of the Geological Survey of Great Britain, who took as his subject, "The Life and Scientific Work of Sir James Hall, Bart., F.R.S. (1761-1832), Second President of the Royal Society of Edinburgh".

Sir James Hall, fourth Baronet of Dunglass, Haddingtonshire, was born on January 17, 1761. He was a great nephew of Sir John Pringle, Bart., the distinguished Army physician, a president of the Royal Society of London. Owing to the early death of Hall's father, Sir John took charge of his education. He attended the Universities of Cambridge, Geneva and Edinburgh. After extensive travel in Europe he settled down at Dunglass, though spending much time at his town house in Edinburgh. In 1786 he married Lady Helen Douglas, a daughter of the Earl of Selkirk.

Hall had been elected a member of the newly formed Royal Society of Edinburgh in 1784, and for many years took a prominent part in the affairs of the Society. He became president in 1812 , being the first scientist to occupy the presidential chair. He was elected Fellow of the Royal Society of London in $\mathbf{1 8 0 6}$.
Though chiefly remembered as a geologist of the Huttonian school, he was always much interested in chemistry, having been a student of Joseph Black, in Edinburgh. His first address to the Royal Society of Edinburgh was on Lavoisier's new theory of chemistry, to which he had been converted by Lavoisier himself, whom he had met a number of times in Paris.

Hall contributed a number of papers to the Edinburgh Transactions, chief among them being his "Account of the Effects of Compression in Modifying the Effects of Heat". This describes the long series of experiments by which he demonstrated that limestone, when heated under pressure, remains undecomposed. This paper has become a classic, and illustrates Hall's great skill as an experimentalist. Hall has been called the 'father of experimental geology', but might, perhaps more aptly, be called the 'father of geochemistry'. His skill as an experimentalist has tended to obscure the fact that he was also an extremely able field-geologist.

Hall was a man of many interests, including, in later life, polities, and he was member of Parliament for the St. Michael division in Cornwall during 18071812. He died in 1832, after suffering ill-health in his later years.

\section{HOSPITAL IN-PATIENTS IN BRITAIN}

\begin{abstract}
A REPORT on the Hospital In-Patient Enquiry for 1959 gives provisional figures for that year and some comparisons with earlier years*. The report is based on data provided by hospitals (other than psychiatric hospitals) in the National Health Service, on forms giving a confidential summary of the case records of a 10 per cent sample of discharges (the term includes deaths). The purpose of the inquiry is to provide statistics to assist the administration of the hospital service and to supplement other statistics about mortality and illness in the community. It is organized jointly by the Ministry of Health and the Central Register Office. 1959 was the second year in which the inquiry had almost complete coverage of the relevant hospitals in England and Wales.

The tables in the report show the diagnostic distribution of case discharges in 1959 and in each year back to 1955 , regional figures for selected important

* Ministry of Health and General Register Office. Report on cospital in-Patient enquiry for the year Tables. Pp. 16. (Iondon: H.M. Stationery Office, 1961.) 18,6d, net.
\end{abstract}

conditions back to 1956 , regional figures for maternity cases according to the type of maternity care received, and the distribution of the cases in the 1959 sample by sex, age and diagnosis. It also includes the estimates of the population of hospital regions by sex and age at June $30,1959$.

There were, in all, $3,664,100$ discharges from the relevant hospitals in 1959 , or $807 \cdot 3$ per 10,000 population, compared with $3,554,700$, or 788.0 per 10,000 in 1958 , an increase of 2.4 per cent. The estimated numbers of discharges for most common causes of admission to hospital showed some increase, though much of this was probably due to more efficient use of hospital services rather than to increased illness.

Respiratory tuberculosis continued to decrease. There were 44,300 discharges in $1959,9 \cdot 8$ per 10,000 population, compared with 48,800 and a rate of 10.8 in 1958. The rates for males fell in all regions except Liverpool, where an intensive mass radiography campaign was held early in the year. 